\title{
Articles
}

\section{Parochial Altruists or Ideologues? An Agent Based Model of Commitment to Self Sacrifice}

\section{by Giti Zahedzadeh}

\section{(cc) $\mathrm{EY}$}

This work is licensed under a Creative Commons Attribution 3.0 License.

\begin{abstract}
What motivates suicide attackers remains an open question. Commitment to suicide missions is puzzling since such behavior is fitness reducing. We model suicide terrorism by drawing on two fundamental human motivations: altruism and selfishness. Martyrdom can be viewed as altruistic- benefiting group members at a cost to oneself, as well as selfish-ideological belief in a profitable afterlife. Our simulations identify that some degree of both behaviors are essential in order to facilitate a commitment to sacrifice. Thus, manipulations of ideology and altruism can tip the threshold and set the agents on the path of martyrdom.
\end{abstract}

Key words: Terrorism; Altruism; Ideology; Agent-based Modeling; Parochialism; Martyrdom.

\section{Introduction}

Suicide terrorism is a violent, politically motivated attack, which is carried out in a deliberate state of awareness (Bloom, 2006: 25). The "strategic logic" of the organizers of suicide missions can be explained in rationalist terms (Pape, 2003; Benmelech \& Berrebi, 2007; Fierke, 2009), however, the choice of suicide volunteers remains problematic since there is a high premium tag on survival (Fierke, 2009). If the projected survival of an act is zero, the expected participation in such an act should also be zero (Ferrero, 2006). Yet throughout history several men and women have made a deliberate choice to end their lives to achieve a perceived public good. What motivates individuals to commit to suicide missions? Martyrdom volunteers exhibit no social dysfunction and do not appear to be discernable from non-martyrs (Margalit, 2003), nor do they express a sense of nothing to lose for lack of life alternatives (Atran, 2003; Horgan, 2005; SanchezCuenca, 2007). Why individuals sacrifice themselves remains poorly understood, and while there exists a multitude of theories (Interdisciplines 2006), there is no consensus around them (Qirko, 2009).

Major analyses of suicide terrorism have devoted considerable effort to motivations (Bloom, 2005; Pedahzur, 2004; Sageman, 2004; Stern, 2003; Kruglanski et al., 2009). However, they have differed in the motives identified as relevant and proposed a broad heterogeneity (for a concise review see Kruglanski et al., 2009). For instance, some authors have highlighted the importance of singular motives (Sageman 2004, Pape 2005), while others have listed a multitude of motivating factors (Stern 2003; Bloom 2005). One method in dealing with such heterogeneity is to partition the flood of motivations into fewer categories (Kruglanski et al., 2009). Indeed, the motives for suicide terrorism can be anchored on the two faces of human social behaviorselfishness and altruism (Wilson et al., 2009). Both motivations concern evolutionary origins, social relations, and the organization of societies (Fehr and Fischbacher, 2003). Altruism, aims to increase another's welfare, 


\section{Journal of Terrorism Research}

and is juxtaposed to selfishness, where the ultimate aim is to maximize one's own (Batson, 2010). Selfishness and altruism are both motivational states, and each is concerned with an ultimate goal- to increase someone's welfare (Batson, 2010). The question remains as whose welfare is to be maximized.

In this study we anchor suicide terrorism motivations' on selfish and altruistic drives. The organization of this paper is as follows. We first introduce the concepts of altruism and selfishness as the two overarching motives propelling suicide terrorism. We then propose a generalized model of suicide terrorism and run the simulations of our propositions. Finally, we explore the implications of our analysis.

\section{The Selfish Martyr}

Ideology is a belief system centered upon some collective ideal and its power resides in its identifying a discrepancy from an ideal state with the aim of removing the discrepancy (Kruglanski et al., 2009) or at the least narrowing the gap. Terrorist recruitment may be more "ideologically driven than grievance-driven" (Atran, 2004). The significance of ideological motivations is highlighted in Kruglanski et al. (2009) analysis of seven farewell videos of suicide terrorists from MEMRI (Middle East Media Research Institute), which found that $5 / 6$ of the terrorists mention religion, $4 / 6$ reaching paradise, and only 2/6 name nationalism (liberation) as their main motivation.

It has been widely speculated that devotion to certain religious beliefs may facilitate support for suicide attacks (Harris, 2005), provide martyrs the reward of an afterlife (Hoffman, 1998), an eternal place in heaven (Rubin, 2002) or contain narratives that glorify acts of combative martyrdom (Rapoport, 1990; Gambetta, 2005). Iannaccone (2003) notes that when a terrorist group locates itself within a sectarian group, it gains access to its social network where members are immersed in a shared set of supernatural beliefs. The religious foundation of martyrdom is the covenant of allegiance that the martyr contracts with God to pave his way toward paradise (Maarouf, 2013). While religion is not the cause of all conflicts involving suicide terrorism, religion is the means by which terrorists may translate a local political struggle into a cosmic war (Juergensmeyer, 2003) and is capable of offering benefits in the afterlife that can hardly be matched in this world (Sosis \& Alcorta, 2008). Suicide terrorism can be motivated by selfish ideology, with religious after-life at its core, and once violence becomes the chosen path, religious radicals can prove to be extremely effective (Berman \& Laitin, 2006).

When suicidal acts stem from strong religious convictions in a glorious destiny from martyrdom and vast rewards in the afterlife, we assume that the perpetrator is motivated by individual benefits. In other words, the advantages of martyrdom, which will be conferred to those who sacrifice themselves, are perceived to be large enough to outweigh the loss of life. In fact, ideology itself removes the cost of martyrdom by providing eternal life. As Kruglanski et al. (2009) note whether "reflecting symbolic immortality and a place in the group's collective memory or concrete immortality as denizens of paradise, paradoxically, the willingness to die in an act of suicidal terrorism may be motivated by the desire to live forever." In a sense then, if a person is truly ideologically engrained, then there is no expectation of death from martyrdom- but a firm belief in future rewards. We call this general class of explanation, selfish ideology.

While these beliefs may seem improbable and dogmatic (Wiktorowicz, 2004), they suggest that individuals have a logical argument in their decision-making portfolio: loyalty to cherished beliefs (Caplan, 2000, 2001). This is while, within a religious-ideological context, emotions can be further manipulated in order to solidify commitment promising future heavenly rewards (Atran, 2003), getting close to God and the desire to enter paradise (Hassan, 2001; Stern, 2003: 125), achieving honor (Bloom, 2005: 87, 145), social status (Stern, 2003 : 


\section{Journal of Terrorism Research}

51, 22, 54, 282; Bloom, 2005: 65), personal significance (Bloom, 2005: 88), attaining respect (Crenshaw, 2007), glamour (Stern, 2003: 51) or becoming "special" such as the case of Black Tamil Tigers who treat martyrs as elite immortals (Kruglanski et al., 2009). Nevertheless, adherence to specific religious ideologies will not explain all human bombing and as Argo (2006) notes, "half of the suicide missions in the three decades before 2003 were carried out by secular rather than religious organizations”.

\section{The Altruistic Martyr}

Suicide terrorism may be empowered by evolutionary forces (Abed, 1997; Trivers, 1985) where sacrifice may serve the individual' s gene pool and/or value system shared by kin (Krugalski et al., 2009). According to Durkheim ([1897] 1951), altruistic suicide may occur when a person becomes deeply integrated into a social group and suicide becomes a duty for the members with the aim of satisfying group objectives. Altruistic dispositions can evolve if the costs they generate provide benefits to an altruist's genetic relatives, as explained by inclusive fitness (Grafen, 2009; Hamilton, 1964). Johnson (1979) argues that people who commit altruistic suicide perceive their own lives as secondary to the interest of the collective. Suicide bombing can be viewed as a strategy to increase inclusive fitness (Rushton, 2005).

Altruistic motives, either alone or in conjunction with others can play an important role in constructing motivations (Pape 2005: 184). However, a particular form of altruism is at work here, which emerges in the context of inter-group conflicts (Bornstein, 2003) and is shaped by parochialism (Choi \& Bowles, 2007). Parochialism refers to a preference for favoring the members of one's ethnic and/or racial group (Bernhard et al., 2006). Parochial altruism is based on the idea that human altruism evolves through the selective (cultural or biological) extinction of groups in inter-group conflicts (Gintis 2000; Henrich \& Boyd 2001; Bowles et al., 2003). Choi and Bowles (2007) suggest that parochial altruism could have emerged and proliferated among early humans because competition for resources favored groups with substantial numbers of parochial altruists willing to engage in hostile conflicts with outsiders on behalf of their group. Further, as Bloom (2006: 28) notes, suicide terrorism plays a greater role in ethnic conflicts when the perpetuators and victims belong to different groups.

Human awareness of mortality can lead to martyrdom when there is a severe threat to group survival (Kruglanski et al., 2009). As one's personal identity is meshed with that of the group (Post et al., 2003), collective survival becomes inseparable from one's own (Kruglanski et al., 2009). Wintrobe (2006) suggests that merging self with the group (leader), referred to as solidarity, can bypass extreme negative costs to the self. In a sense then, the need for emotional and social support when experiencing alienation (Sageman, 2004), group pressure (Bloom, 2005: 85), honor (Bloom, 2005: 87, 145), dedication to the leader (Bloom 2005: 64), pain and personal loss (Bloom, 2005: 35, 86-87, 145), moral obligation, need to belong, financial support for family, friendship (Stern, 2003: 47), occupation (Stern, 2003: 57, 59, 136), and furthering the interests of the group (Gambetta, 2005) can serve parochial altruists where disputes serve as motivators for aggressive traits.

Can dissatisfaction motivate commitment to suicide missions? Dissatisfaction with the status quo such as resistance to foreign occupation (Pape, 2005), personal loss or trauma (Spekhard \& Akhmedova, 2005), vengeance and humiliation from suffering injustice (Bloom, 2005; Ricolfi, 2005; Stern, 2003), and significance loss (relative deprivation) (Kruglanski et al., 2009) can serve as precursors for suicide terrorism. In a sense, if an individual is satisfied with the status quo there should be no reason to volunteer for suicide missions in 
order to change the status quo. By the same token, dissatisfaction without the necessary ingredients- selfish ideology or parochial altruism- cannot compel commitment to suicide missions.

We model suicide terrorism by drawing on parochial altruism and selfish ideology. Our aim is to simulate a ruled-based computational model of commitment to suicide missions. Agent based models (ABM) simulate real-world systems with a group of interacting agents modeled as computer programs to study the interactions of the agents and/or emerging behaviors (Chan, 2008). We will consider agents' level of dissatisfaction with the status quo and discuss preliminary findings, as well as implications for future research. Details of the model are provided in the next section.

\section{Generalized model}

$\mathrm{ABM}$ represents a novel approach to investigate emerging behaviors under certain parameters. ABM is a natural method for describing and simulating a system composed of real-world entities (Gilbert \& Terna, 2000) and is more akin to reality than other modeling approaches (Crooks \& Heppenstall, 2010). Thus, our simulations will provide an opportunity to represent and test propositions, which cannot easily be described using mathematical formulae (Axelrod, 1997) nor tested in non-simulated life.

Implemented in Netlogo (5.0.5), our model[1] involves one category of agents $(A)$ who are members of the general population. We consider a population in which agents live, gain their energy from available natural resources (grass represented by green patches) and reproduce (see supplemental material). Agents are heterogeneous in one respect- their level of dissatisfaction with the status quo $\left(D_{S Q}\right)$. The attributes and behavioral rules of the agents are as follows.

\section{Agent specifications}

The model includes a representation of each agent's possible motivations (parochial altruism, selfish ideology) and $D_{S Q^{\circ}}$ Group motivation $\left(M_{\text {Group }}\right)$ is partitioned into two components: $D_{S Q}$ and parochial altruism $\left(I_{a}\right)$. Their definitions are as follows: $D_{S Q}$ is the agents' perceived dissatisfaction with the status quo and is assumed to be heterogeneous across agents. Each individual value is drawn from $U(0,1)$, the uniform distribution on the interval $(0,1) . I_{a}$ is parochial altruism. $I_{a}$ is exogenous and equal across agents, and in the runs discussed below, will be varied over arbitrarily defined range of 0 to 1 . Thus, $M_{\text {Group }}$ is the product of $D_{S Q}$ and $I_{a \text {. }}$ The intuition behind this formulation is the following: $D_{S Q}$ and $I_{a}$ are expected to produce the motivation to mobilize agents to serve the group. We assume:

$$
D_{S Q}^{*} I_{a}
$$

Ideology generally means a belief system centered upon some social or collective ideal (Kruglanski et al., 2009), and may be explained in terms of the emotional motivations of its adherents. Motivation and ideology are separate concepts, however as they play out in the model they are intertwined. This is because without ideology there can be no motivation from that ideology. It is possible that people vary in their belief in "benefits" of martyrdom but for this model we will keep it constant, assuming that low motivation is reflecting low belief. Thus, we incorporate $I_{s}$ in the model, representing selfish ideology. $I_{s}$ is exogenous and equal across agents, and will be varied over its arbitrarily defined range of 0 to 1 . We have now captured the motivation to commit to missions $\left(M_{\text {Mission }}\right)$. We assume:

$$
\left(D_{S Q}^{*} I_{a}\right)+I_{s}
$$




\section{Journal of Terrorism Research}

The model will not be complete without some representation of cost $(C)$. Since we are modeling an extreme behavior where the probability of survival is near zero. $C$ is the agent's perceived cost of committing to a suicide missions. $C$ is exogenous and equal across agents, and will be varied over an arbitrarily defined range of 0 to 1 . Thus, we assume:

$$
\left[\left(D_{S Q}{ }_{a}^{*}\right)+I_{S}\right]-C
$$

If for the agents, the difference $\left[\left(D_{S Q}{ }^{*} I_{a}\right)+I_{s}\right]-C$ reaches the threshold $(T)$, then the quiescent $(Q)$ agents will commit to the path of martyrdom and become active $\left(A_{\text {Active }}\right)$. Otherwise, they stay quiescent. The threshold is usually set at some small (0.1) positive value (e.g. see pstein (2002) for threshold setting). Hence, the agents' simple rule-based model is the following Rule $M_{\text {Rule }}$ :

$$
\left[\left(D_{S Q}^{*} I_{a}\right)+I_{s}\right]-C \geq T
$$

Agent $i$ evaluates her level of dissatisfaction and then calculates her level of commitment to the mission. We intentionally constrain the values for $C, I_{a}$ and $I_{s}$, since we are interested in capturing the behavioral outcomes under controlled conditions.

Although our model is preliminary, it does produce interesting phenomena and therefore, can be used to explore sacrificial behavior. Since the run-time visualization of model output is useful, our graphic strategy is as follows.

\section{Graphics}

Events transpire on a lattice. Agents move around this space. Values for $C, I_{a}$ and $I_{s}$ are set by the user and drawn from $U(0,1)$. Initially, all agents appear on the lattice as red circles $\left(A_{\mathrm{S}}\right)$. After the initial tick, agents, whose $D_{S Q}$ reaches a 0.5 cutoff point will turn blue otherwise they remain red circles. Even though blue circles are dissatisfied $\left(A_{D}\right)$, their calculation does not reach the threshold and fails to set them on the path of martyrdom. Instead, these are the type of people that may provide other support for terrorist organizations (e.g. financial support, message propagation). However, those who commit to martyrdom missions transform to triangles and turn black ( $A_{\text {Active }}$ or active cells). The agents also build links with those in their proximity (same patch) only if their level of dissatisfaction is shared with nearby others. The model simply iterates this procedure until the user quits. The aim of addressing these spheres is to permit illustration of core areas in suicide terrorism research with regard to motivations. Thus, our simulations explore the properties of our model under a range of propositions.

Runs

To begin each run of the model, the user sets $C, I_{a}, I_{s}$ and the initial agent density. To ensure replicability of the results, input assumptions for all runs are provided in Table 1. All runs have the following configurations: lattice dimensions (16_16); initial population (25), and patch-size (9.24). $\mathrm{R}$ is random. Initial agents choose their values for $D_{S Q}$, and are situated randomly on the lattice. The model then simply spins forward and agents move to random sites, where they act in accordance with $M_{\text {Rule }}$. The model simply iterates this procedure until the user quits. To explore how the dynamic relationship affects the evolution of commitment to missions, 10,000 simulation runs-each initialized using the same set of standard variable values were executed for each combination of the experimental variables. 


\section{Journal of Terrorism Research}

\begin{tabular}{llllll}
\hline Variable & Run 1 & Run 2 & Run 3 & Run 4 & Run 5 \\
\hline$D$ & $\mathrm{R}$ & $\mathrm{R}$ & $\mathrm{R}$ & $\mathrm{R}$ & $\mathrm{R}$ \\
$I_{a}$ & 0.20 & 0.90 & 0.56 & 0.80 & 0.10 \\
$C$ & 1.0 & 1.0 & 1.0 & 1.0 & 1.0 \\
$I_{s}$ & 0.90 & 0.20 & 0.56 & 0.80 & 0.10 \\
\hline
\end{tabular}

Table 1. Input assumptions for runs

\section{Propositions}

We state several propositions and then run the computational model to explore the emerging behavior of the agents. The parameters of each proposition are detailed below to ensure replicability. Since successful martyrdom missions end with the death of the bomber, we assess the model at Cost ${ }_{\text {max }}$ First, we study highly ideological agents and set parochial altruism at some low value. This is idealized, however, it allows an investigation of the strength of $I_{s}$.

Proposition 1: If $I_{a}=0.20, C=1.0, I_{s}=0.90 \geq T$

Run 1- We run the model and find that under these conditions agents do not commit to missions (Figure 1). We increase $I_{a}$ slightly (by 0.01), and rerun the model. This time we observe that a few agents commit (Figure 2). While, ideology is a strong facilitator of commitment, from an agent's point of view, some parochial altruism is necessary to reach the threshold. Under these conditions, parochial altruism must be higher than $20 \%$ in order to push a few to commit. Since the number of $A_{\text {Active }}$ is low at the initial tick $(\mathrm{n}=2$; and the number may vary at each initialization), the probability of survival of like-minded agents decreases as time advances.

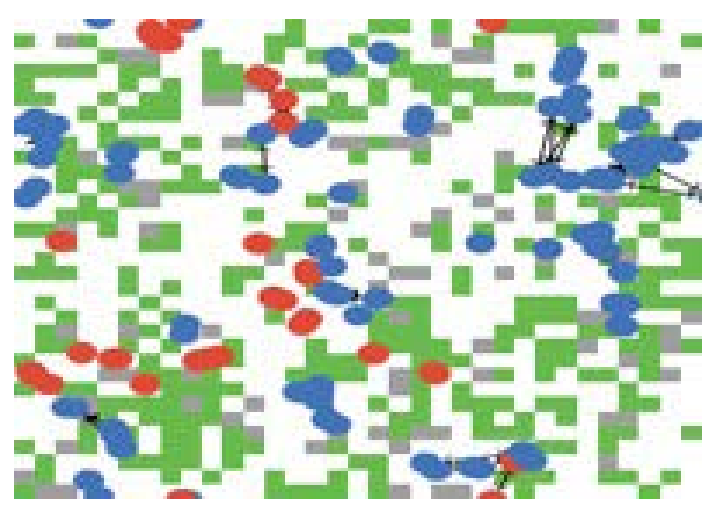

Figure 1. (a) None of the agents commit. 


\section{Journal of Terrorism Research}

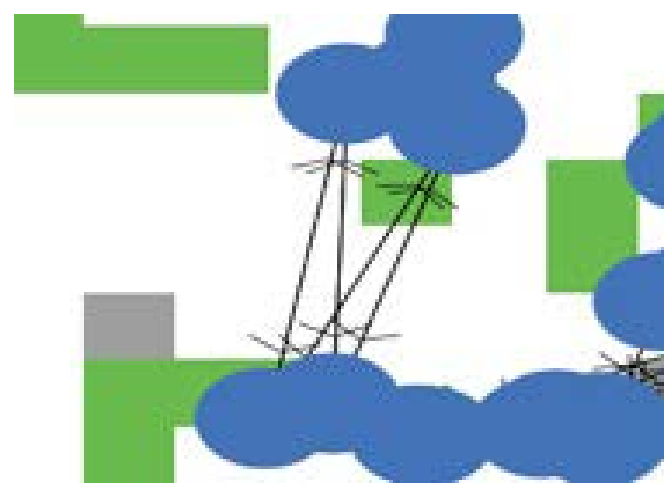

Figure 1. (b) Enlarged section shows agents who have built ties.

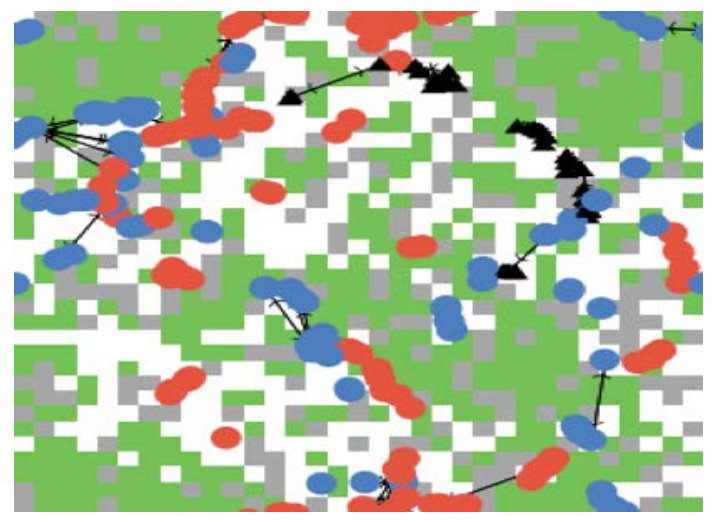

Figure 2. Some agents commit $\left(A_{\text {Active }}=39\right)$. The model is paused at 18 ticks.

We are now interested to know whether parochial altruism can produce similar results. We assume agents are high parochial altruists.

Proposition 2: If $I_{a}=0.90, C=1.0, I_{s}=0.20 \geq T$

Run 2- After the initial tick, the model produces no martyrs. As in the previous proposition, we increase ideology by 0.01 and then observe that some agents commit to missions (Figure 3 ). The simulation show that neither $I_{s}$ and $I_{a}$ in isolation can produce commitment to a mission when success is fitness reducing. Thus, in order to recruit successfully both elements need to be entertained. 


\section{Journal of Terrorism Research}

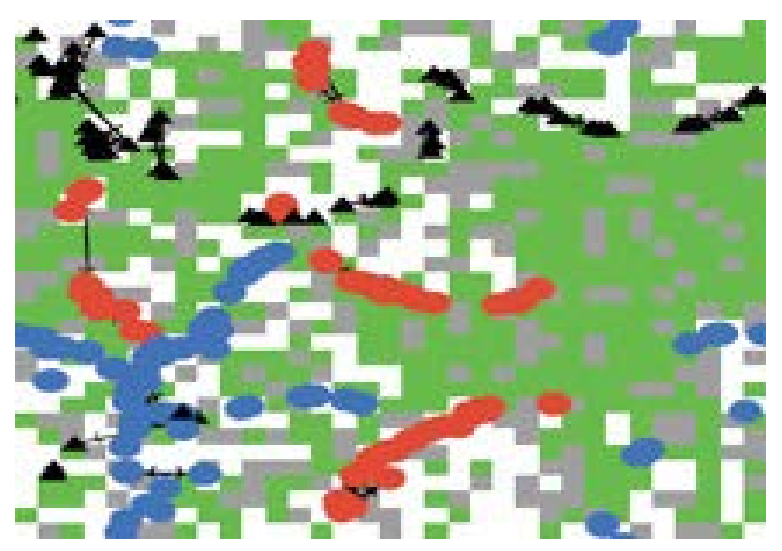

Figure 3. Some agents commit $\left(A_{\text {Active }}=96\right)$. The model is stopped at 16 ticks.

Next, we are interested to know the minimum $I_{s}$ and $I_{\mathrm{a}}$ values necessary to compel agents' commitment. We set both $I_{a}$ and $I_{s}$ at 0.5 while keeping $C$ at its max. We find that none of the agents commit. Thus, we propose the following proposition:

Proposition 3: If $I_{a}=0.56, C=1.0, I_{s}=0.56 \geq T$

Run 3- While the model does not always produce agents who commit, it does so at random intervals (Figure 4). Agents cluster with those who share their level of dissatisfaction and ties are directed towards those who share agent's evaluation of the status quo. While agents build ties with those who share their $D_{\mathrm{SQ}}$, the ties do not constrain movement. The ties break once an agent dies.

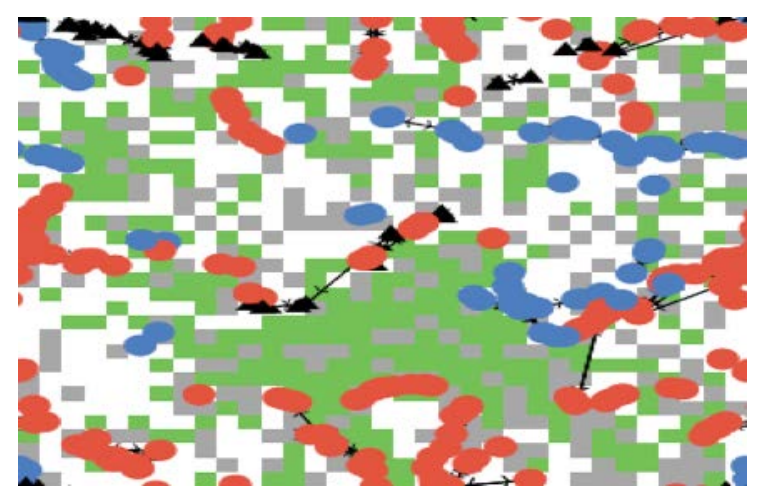

Figure 4. The model is paused at tick 15. $A_{M}=46$.

In all the propositions so far we have observed groups of dissatisfied agents who have remained quiescent. By setting both $I_{a}$ and $I_{s}$ at $80 \%$, we expect to see a decline in the number of dissatisfied agents. Thus, we introduce our final proposition.

Proposition 4: If $I_{a}=0.80, C=1.0, I_{s}=0.80 \geq T$

Run 4. We pause the simulation at tick $300\left(A_{S}=102, A_{M}=80, A_{D}=0\right)$. As expected, we observe that only two categories of agents emerge: $A_{\text {Active }}$ and $A_{s}$. Regardless of their initial level of satisfaction, high values of $I_{a}$ and $I_{s}$ can instigate more committed agents. Thus, high manipulations of selfish ideology and parochial altruism 
can induce agents who otherwise would not have committed to sacrificial missions. Agents are either satisfied or committed to self-sacrifice. We derive two conclusions: First, this sheds light on the phenomenon of lone wolf terrorists or those who self select to join terrorist networks while committing to distant causes. While lone wolves may not directly be impacted by distant causes, manipulations of ideology and altruism can transform otherwise quiescent individuals. Second, the model explains the existence of a collective action problem and free riding. At low values of $I_{a}$ and $I_{s}$, agents remain satisfied/dissatisfied but quiescent. They may agree with the few active agents but do not self-sacrifice (free riding). Thus, manipulations of $I_{a}$ and $I_{s}$ pushes the limits of tolerance where self-sacrifice becomes the preferred option resolving the collective action problem.

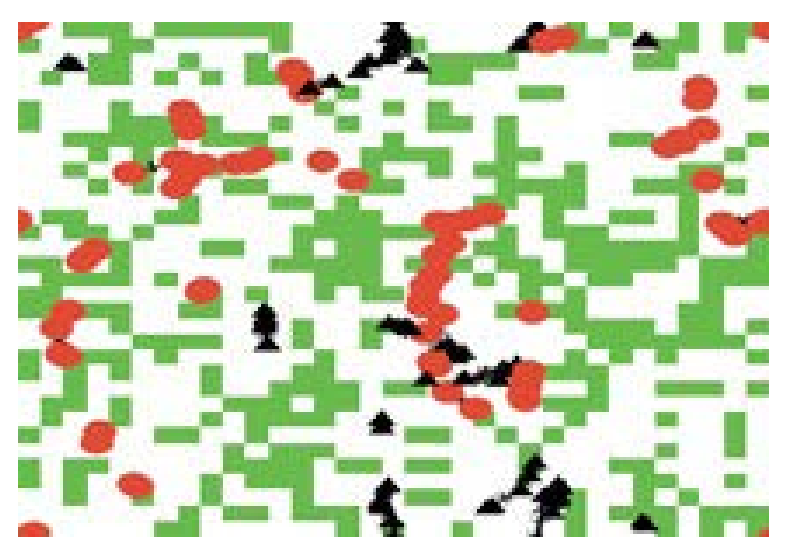

Figure 5. There are no dissatisfied agents.

Proposition 5: If $I_{a}=0.10, C=1.0, I_{s}=0.10 \geq T$

Run 5. Finally we run the model at low values of $I_{a}$ and $I_{s}$. As expected only satisfied and dissatisfied agents are observed on the lattice. $I_{a}$ and $I_{s}$ can not overcome the high cost of self sacrifice, and thus, agents calculation do not reach the threshold.

\section{Conclusion}

Although our model is exploratory and preliminary, it does produce interesting phenomena. First, we find both selfish ideology and parochial altruism to be strong facilitators of commitment to martyrdom missions. However, they do not force engagement in complete isolation of one another and some degree of ideology and altruism is necessary to motivate commitment. Thus, the model shows that extreme sacrificial behavior can be elicited under an ideological veil (e.g. Atran, 2003) and/or altruistic motives (Pedahzur \& Perliger, 2003). It explains why terror organizations need to frame martyrdom as beneficial to the group (community) in order to override the cost burden introduced to the volunteer's decision-making calculations. Indoctrination and manipulation of beliefs by the recruiters serve this goal and prepare the next generation of suicide terrorists. Second, in the first three propositions, we observed dissatisfied agents who nevertheless remained quiescent. However, at high values of selfish ideology and parochial altruism, we observed a dramatic decline in the number of dissatisfied agents. Thus, manipulations of ideology and altruism introduced in individuals' calculations can tip the threshold and set the agents on the path of martyrdom. People that may have otherwise provided other support for terrorist organizations (financial, message 
propagation) would now commit. Third, as the number of agents at each level of satisfaction increases (overtaking other groups in terms of number), so does that group's chance of survival. Halverston et al. (2013: 313) explain this in terms of a master narrative where contemporary events are understood through a preexisting framework, and the individual's personal narrative is woven throughout. Hence, suicide terrorism may be viewed as an inter-generational investment (Azam, 2003). Finally, the model shows clustering of similar agents as like-minded others stay close together and build networks with those who share their evaluation of the status quo.

The model introduced here aims to address a principal question, which serves as the focus of this paper. Given certain assumptions, does parochial altruism or selfish ideology facilitate commitment to suicide missions? This is an important question since recruiters and trainers can manipulate emotionally driven commitments to inspire action in otherwise paralyzing conditions (Atran, 2003). The model simulates this phenomenon where increasing the values of ideology and altruism can transform- dissatisfied but quiescent agents- into committed cells. Terror organizations can perpetuate altruistic behavior through manipulation of kinship-recognition cues intended to maintain and reinforce commitment (e.g. see Quirko, 2009). On the other hand, ideology is a powerful facilitator where promises of afterlife rewards are perceived as large enough to outweigh personal disadvantages accrued- providing a selfish reason to pursue a sacrificial venture at a cost. We agree with Atran (2003) that in order to fight terrorism effectively, we need to investigate which configurations of psychological, religious, and cultural relationships lure individuals into martyrdom-making networks. Thus, in future studies we aim to address how these pathways can be manipulated in order to reconfigure recruitment strategies to advantage counterterrorism policies.

\section{Acknowledgments}

The author would like to thank Professor Jorge A. Barraza for useful discussions and critical reading of the manuscript.

\section{About the author}

Giti Zahedzadeh is a PhD candidate in the Department of Politics \& Policy at Claremont Graduate University and also serves as Research Associate at the Center for Neuroeconomics Studies.

\section{Notes}

[1] For an introduction to agent-based modeling, see Epstein and Axtell (1996; also see Epstein's Computational Model of Civil Violence, 2002).

\section{References}

Abed, R. T. (1997). "Suicide as altruism: A Darwinian perspective." Irish Journal of Psychological Medicine. 14(04), 144-146.

Argo, N. (2006). "Human bombs: Rethinking religion and terror." MIT Center for International Studies Audit of the Conventional Wisdom. 06-07.

Atran, S. (2003). “Genesis of suicide terrorism.” Science. 299(5612), 1534-1539.

Atran, S. (2004). “Mishandling suicide terrorism.” Washington Quarterly. 27(3), 65-90. 


\section{Journal of Terrorism Research}

Axelrod, R. (1997). Advancing the art of simulation in the social sciences. In Simulating social phenomena (pp. 21-40). Springer Berlin Heidelberg.

Batson, C. D. (2010). Empathy-induced altruistic motivation. Prosocial motives, emotions, and behavior: The better angels of our nature, 15-34.

Benmelech, E., \& Berrebi, C. (2007). “Human capital and the productivity of suicide bombers." The Journal of Economic Perspectives. 21(3), 223-238.

Bernhard, H., Fischbacher, U., \& Fehr, E. (2006). "Parochial altruism in humans." Nature. 442(7105), 912-915.

Berman, E., \& Laitin, D. D. (2008). “Religion, terrorism and public goods: Testing the club model." Journal of Public Economics. 92(10), 1942-1967.

Biron, D. G., Marché, L., Ponton, F., Loxdale, H. D., Galéotti, N., Renault, L., \& Thomas, F. (2005).

"Behavioural manipulation in a grasshopper harboring hairworm: a proteomics approach." Proceedings of the Royal Society B: Biological Sciences. 272(1577), 2117-2126.

Bloom, M. (2005). Dying to kill: The allure of suicide terror. Columbia University Press.

Bornstein, G. (2003). “Intergroup conflict: Individual, group, and collective interests.” Personality and social psychology review. 7(2), 129-145.

Bowles, S., Choi, J. K., \& Hopfensitz, A. (2003). The co-evolution of individual behaviors and social institutions. Journal of theoretical biology, 223(2), 135-147.

Caplan, B. (2000). “Rational irrationality: a framework for the neoclassical-behavioral debate." Eastern Economic Journal. 26(2), 191-211.

Caplan, B. (2006). “Terrorism: The relevance of the rational choice model.” Public Choice. 128(1-2), 91-107. Caplan, B. (2002). "Sociotropes, systematic bias, and political failure: reflections on the Survey of Americans and Economists on the Economy." Social Science Quarterly. 83(2), 416-435.

Chan, W. K. V. (2008). "An analysis of emerging behaviors in large-scale queueing-based service systems using agent-based simulation.” In Simulation Conference. WSC 2008. Winter (pp. 872-878). IEEE.

Choi, J. K., \& Bowles, S. (2007). “The coevolution of parochial altruism and war." Science. 318(5850), 636-640. Crenshaw, M. (2007). “Explaining suicide terrorism: A review essay.” Security Studies. 16(1), 133-162.

Crooks, A. T., \& Heppenstall, A. J. (2012). "Introduction to agent-based modelling." In Agent-based models of geographical systems (pp. 85-105). Springer Netherlands.

Davies, N. B. (2011). Cuckoos, cowbirds and other cheats (Vol. 63). A\&C Black.

Durkheim, E. (1897). 1997. Suicide. New York: Free Press.

Epstein, J. M. (2002). “Modeling civil violence: An agent-based computational approach." Proceedings of the National Academy of Sciences of the United States of America. 99(3), 7243-7250.

Fehr, E., \& Fischbacher, U. (2003). “The nature of human altruism.” Nature, 425(6960), 785-791.

Ferrero, M. (2006). “Martyrdom contracts.” Journal of Conflict Resolution. 50(6), 855-877.

Fierke, K. M. (2009). “Agents of death: the structural logic of suicide terrorism and martyrdom.” International Theory. 1(01), 155-184.

Gambetta, D. (Ed.). (2005). Making sense of suicide missions. Oxford: Oxford University Press. 


\section{Journal of Terrorism Research}

Gilbert, N., \& Terna, P. (2000). "How to build and use agent-based models in social science." Mind \& Society, $1(1), 57-72$.

Gintis, H. (2000). "Strong reciprocity and human sociality." Journal of theoretical biology, 206(2), 169-179.

Grafen, A. (2009). "Formalizing Darwinism and inclusive fitness theory." Philosophical Transactions of the Royal Society B: Biological Sciences, 364(1533), 3135-3141.

Halverson, J. R., Ruston, S. W., \& Trethewey, A. (2013). "Mediated Martyrs of the Arab Spring: New Media, Civil Religion, and Narrative in Tunisia and Egypt." Journal of Communication. 63(2), 312-332.

Hamilton, W. D. (1964). “The genetical evolution of social behavior." Journal of theoretical biology, 7(1), 1752.

Harris, S. (2005). The end of faith: Religion, terror, and the future of reason. WW Norton \& Company.

Hassan, N. (2001). "An Arsenal of Believers." The New Yorker, November 21. http://www.newyorker.com/ magazine/2001/11/19/an-arsenal-of-believers

Henrich, J., \& Boyd, R. (2001). "Why people punish defectors: Weak conformist transmission can stabilize costly enforcement of norms in cooperative dilemmas." Journal of theoretical biology, 208(1), 79-89.

Hoffman, B. (2013). Inside terrorism. Columbia University Press.

Horgan, J. (2008). "From profiles to pathways and roots to routes: Perspectives from psychology on radicalization into terrorism." The ANNALS of the American Academy of Political and Social Science. 618(1), 80-94.

Iannaccone, L. R. (2006). “The market for martyrs.” Interdisciplinary Journal of Research on Religion. 2(4), $1-28$.

Interdisciplines. 2006. “Understanding Suicide Terrorism.” Online Conference. http://www.interdisciplines. org/terrorism.

Irons, W. (1996). “In Our Own Self Image: The Evolution of Morality, Deception, and Religion.” Skeptic. 4(2): 50-61. 1996.

Juergensmeyer, M. (2003). Terror in the mind of God: The global rise of religious violence (Vol. 13). Univ of California Press.

Johnson, K. K. (1979). Durkheim revisited: “Why do women kill themselves?" Suicide and Life-Threatening Behavior. 9(3), 145-153.

Johnson, G. R., Beer, F. A., van den Berghe, P. L., Rushton, J. P., \& Rushton, J. P. (1986). "Kin Selection, Socialization, and Patriotism: An Integrating Theory [with Commentaries]." Politics and the Life Sciences. $4(2), 127-154$.

Johnson, G. R. (1989). “The role of kin recognition mechanisms in patriotic socialization: Further reflections." Politics and the Life Sciences. 8(1), 62-69.

Johnson, G. R., Ratwik, S. H., and Sawyer, T. J. (1987). The evocative significance of kin terms in patriotic speech. In V. Reynolds, V. Falger and I. Vone (Ed.), The sociobiology of ethnocentrism: Evolutionary dimensions of xenophobia, discrimination, racism, and nationalism (pp. 137-174). Routledge Kegan \& Paul.

Johnson, J. L., McAndrew, F. T., and Harris, P. B. (1991). "Sociobiology and the naming of adopted and natural children." Ethology and sociobiology. 12(5), 365-375. 


\section{Journal of Terrorism Research}

Krueger, A. B., \& Malečková, J. (2003). “Education, poverty and terrorism: Is there a causal connection?” The Journal of Economic Perspectives. 17(4), 119-144.

Kruglanski, A. W., Chen, X., Dechesne, M., Fishman, S., and Orehek, E. (2009). "Fully committed: Suicide bombers' motivation and the quest for personal significance." Political Psychology. 30(3), 331-357.

Maarouf, M. (2013). "Suicide Bombing: The Cultural Foundations of Morocco's New Version of Martyrdom." Journal of Religion and Popular Culture. 25(1), 1-33.

Margalit, A. (2003). “The suicide bombers.” New York Review of Books. 50(1), 36-39.

Qirko, H. (2002). “The Institutional Maintenance of Celibacy.” Current anthropology. 43(2), 321-329.

Qirko, H. (2004). “Altruistic Celibacy, Kin-Cue Manipulation, and The Development of Religious

Institutions." Zygon ${ }^{\bullet}$ 39(3), 681-706.

Qirko, H. N. (2009). “Altruism in suicide terror organizations.” Zygon. 44(2), 289-322. Qirko, H. N. (2013).

"Induced altruism in religious, military, and terrorist organizations." Cross-Cultural Research. 37, 131-161.

Pape, R. A. (2003). “The strategic logic of suicide terrorism.” American political science review. 97(03), 343361.

Pape, R. (2005). Dying to win: The strategic logic of suicide terrorism. Random House.

Pedahzur, A. (2004). "Toward an analytical model of suicide terrorism-A comment." Terrorism and Policical Violence, 16(4), 841-844.

Post, J., Sprinzak, E., \& Denny, L. (2003). “The terrorists in their own words: Interviews with 35 incarcerated Middle Eastern terrorists" Terrorism and political Violence. 15(1), 171-184.

Rapoport, D.C. (1990). Sacred Terror: A Contemporary Example From Islam. In W. Reich (Ed.), Origins of Terrorism: Psychologies, Ideologies, Theologies, States of Mind (pp. 103-130). Woodrow Wilson International Center for Scholars, Cambridge University Press.

Ricolfi, L. (2005). Palestinians, 1981-2003. In D. Gambetta (Ed.), Making Sense of Suicide Missions (pp. 77129). Oxford: Oxford University Press.

Rothstein, S. I. and S. K. Robinson, S. K. (1998). The Evolution and Ecology of Avian Brood Parasitism. In S. I. Rothstein and S. K. Robinson (Ed.), Parasitic Birds and their Hosts: Studies in Coevolution, (pp. 3-56). New York, NY: Oxford University Press.

Rubin, E. (2002). The Most Wanted Palestinian. The New York Times Magazine, June 30. http://www.nytimes. com/2002/06/30/magazine/the-most-wanted-palestinian.html

Rushton, J. P. (2005). "Ethnic nationalism, evolutionary psychology and Genetic Similarity Theory." Nations and Nationalism, 11(4), 489-507.

Sageman, M. (2004). Understanding terror networks. University of Pennsylvania Press.

Sánchez-Cuenca, I., and De la Calle, L. (2009). "Domestic terrorism: The hidden side of political violence." Annual Review of Political Science. 12, 31-49.

Stern, J. (2003). Terror in the name of God: Why religious militants kill. New York: Ecco.

Sosis, R and Alcorta, C. (2008). Militants and Martyrs: Evolutionary Perspectives on Religion and Terrorism. In Sagarin, R.D. and Taylor T. Natural security: A Darwinian approach to a dangerous world, (pp. 105-124). University of California Press. 


\section{Journal of Terrorism Research}

Speckhard, A., and Akhmedova, K. (2005). “Talking to terrorists.” Journal of Psychohistory. 33(2), 125-156

Trivers, R.L. (1985). Social evolution. Menlo Park, CA: Benjamin/Cummings.

Victoroff, J. (2005). “The Mind of the Terrorist: A Review and Critique of Psychological Approaches.” Journal of Conflict resolution. 49(1), 3-42.

Wagner, P. J. (1995). “Testing evolutionary constraint hypotheses with early Paleozoic gastropods.” Paleobiology, 248-272.

Wilson, D. S., O’Brien, D. T., \& Sesma, A. (2009). "Human prosociality from an evolutionary perspective: variation and correlations at a city-wide scale." Evolution and human behavior, 30(3), 190-200.

Wiktorowicz, Q. (2004). Introduction. In Wiktorowicz, Q (Ed.), Islamic activism: A social movement theory approach, (pp. 1-33). Bloomington: Indiana University Press.

Wintrobe, R. (2006). “Extremism, suicide terror, and authoritarianism.” Public Choice. 128(1-2), 169-195.

Yanoviak, S. P., Kaspari, M., Dudley, R., and Poinar Jr, G. (2008). "Parasite-induced fruit mimicry in a tropical canopy ant." The American Naturalist. 171(4), 536-544. 